\title{
STUDIES IN CANCER. VII. ENZYME DEFICIENCY IN HUMAN AND EXPERIMENTAL CANCER ${ }^{1}$
}

\author{
By R. C. ROSKElley, ${ }^{2}$ NELICIA MAYER, ${ }^{3}$ B. N. HORWITT, ${ }^{4}$ and W. T. SALTER \\ (From the Department of Pharmacology, Yale University School of Medicine, with the \\ cooperation of the Nerw Haven Hospital, New Haven)
}

(Received for publication March 2, 1943)

The biochemistry of cancer tissue in experimental animals has been studied extensively. In particular, the behavior of certain enzyme systems in animal tissues has been described. Despite the obvious desirability of understanding the chemical pathology of human cancer, however, there is as yet little information on human tissues. Many of the methods employed in pre-clinical laboratories necessitate the availability of pure-type tumors in considerable numbers, and involve the sacrifice of the animal host. Therefore, such procedures are not directly applicable in the clinic. Obviously, in human cases, it is possible to have surviving samples of neoplasms taken as biopsies or as material excised at operation. Under such circumstances, however, one must be prepared to deal with a wide variety of tissue architectures, complicated by varying degrees of invasion by stroma, hemorrhage, or necrosis. Only by devising simplified methods to cope with these complications can one hope to extend the findings of experimental research to human cancers.

One such procedure has been described in a previous communication (1). This involved the study of the succinoxidase and cytochrome systems in neoplastic tissues. The fundamental fact upon which it was based was the report by several investigators ( 2 to 4 ) that a deficiency of cytochrome was characteristic and perhaps even universal in neoplasia. Such measurements have been based, in part, upon the low intensity of the $A$ and $B$ bands observed in extracts of tumor tissue or in sections of the surviving tumor (5).

It is particularly important to have available quantitative procedures for such studies, because those differences between normal and cancerous

\footnotetext{
1 Aided by grants from the Jane Coffin Childs Fund and the International Cancer Research Foundation.

2 Jane Coffin Childs Memorial Fellow in Pharmacology.

${ }^{3}$ Finney-Howell Research Fellow in Pharmacology.

4 Research Fellow in Pharmacology.
}

tissue, now recognized, are quantitative rather than qualitative in nature (6). This paper advances evidence that the striking lack of differentiation, characteristic of malignant tissue, is accompanied by striking differences in the enzymic complement of cancer cells.

The precise enzymic pathways by which molecular oxygen is activated are still imperfectly understood. The minimum components known in the two systems studied in the present investigation were as follows:
I. $\mathrm{O}_{2} \rightarrow$ cytochrome oxidase $\rightarrow$ cytochrome-c $\rightarrow \mathrm{p}$-phenylenediamine
II. $\mathrm{O}_{2} \rightarrow$ cytochrome oxidase $\rightarrow$ cytochrome- $-\mathrm{c}$ $\rightarrow$ succinic dehydrase $\rightarrow$ succinate

The low cytochrome-system responsiveness in neoplastic tissue is particularly important because this group of enzymes is known to furnish the main pathway by which oxygen is fed to vital combustive processes occurring in most normal cells. It is, therefore, a significant physiologic unit to study when inquiring into the likelihood that a given tissue is neoplastic.

In this connection, several interesting questions present themselves. When neoplastic cells arise, does this physiologic unit disappear suddenly, or is there a gradual loss of its activity as the tissue goes through a pre-cancerous stage? If a certain tissue which the pathologist terms "precancerous" is examined for the activity of this physiological system, will its activity be found to be high or low? Is the loss of this highly specialized, oxidative pathway a pre-requisite step in the conversion of a normal tissue to a malignant one? Finally, are the data on this subject already available in experimental laboratory animals applicable to the human disease? These are some of the questions which it might be possible to illuminate by applying specially designed methods to tissues obtained in the hospital operating room. 


\section{EXPERIMENTAL METHOD}

The biochemical procedure followed in the present investigation was described in detail in a previous report (1), and its applicability to homologous pairs of normal and malignant animal tissues was demonstrated. In brief, this method measured the responsiveness of the succinoxidase or cytochrome systems in increasing their effectiveness above the natural endogenous rate of oxidation. An optimal concentration of substrate was used to enforce maximal activity of the enzyme system. The relative increase in oxidation is termed the "cytochrome system responsiveness" or the "succinoxidase responsiveness," expressed as percentage increase above the control level. In the present instance, the procedure has been modified by adjusting the working concentration both of succinate and of paraphenylenediamine to $0.02 \mathrm{M}$. The single vessel, manometric technique of Warburg (7) was employed in recording respiration. For the measurement of both aerobic and anaerobic glycolysis, the single vessel method was used.

The specimens were controlled by collateral histological studies by Dr. H. S. N. Greene. In sampling the tissue, care was taken that adjacent portions were used respectively for the control and test manometric vessels, in order to compensate for incidental changes in the structure of the tumor. Similarly, after removal of the thin slices for biochemical study, the adjacent tissue was preserved for pathological examination. Further details may be found in the previous report (1).

In preliminary animal studies, 3 types of material have been used. These were (a) fleshy tumors, transplanted into pure-strain mice; (b) Shope virus papilloma in rabbits; and (c) hepatoma produced in rats of the Wistar strain by the addition of butter yellow to the flavine-deficient diet described by Kensler, Sugiura, and Rhoads (8). It will be noted that in the latter two instances it was possible to follow a standard tissue at various intervals during its transition from strict normality to frank malignancy. In addition, these data have been supplemented by studies of human embryos at advancing ages in order to learn the effect of progressive differentiation in the normal foetus. These last data will be reported elsewhere.

In sampling the animal tissues, the neoplasm or con. trol normal tissue was maintained in cold Ringer's-glucose solution until slices of it were placed in the Warburg vessel. The total time elapsing was about one hour. In the case of the human tissues, the specimen obtained in the operating room was covered with cold normal saline solution and rapidly transported to the laboratory, a distance of several hundred yards. Thereafter, it was treated precisely as were the animal tissues.

In a few instances, tests were made of the effect of preserving such tissues under Ringer's solution or saline in the icebox for several hours, or even overnight. Interestingly enough, such tissues appeared to yield the same relative results as the fresh tissues, although the absolute rate of respiration might decline by as much as one-fifth.
EXPERIMENTAL DATA

\section{Hepatoma induced by butter yellow}

Rats of the Wistar strain were fed exclusively the diet described by Kensler, Sigiura, and Rhoads (8). This diet contained, per kilo, $20 \mathrm{cc}$. of olive oil containing 3 per cent of butter yellow, mixed with finely ground brown rice. A supplement of 1.5 grams of fresh carrot per animal was supplied each day. Several dozen such animals were maintained under identical conditions. At successive time intervals, ranging from 21 days to 180 days, the test animals were sacrificed. Their livers were removed rapidly and collateral biochemical and histologic examinations were made. The results are summarized in Table $I$ and illustrated for succinoxidase by Figure 1. As will be clear from

TABLE I

Butter yellow (rats)

\begin{tabular}{|c|c|c|c|c|c|}
\hline \multirow{2}{*}{$\begin{array}{c}\text { Days on } \\
\text { butter } \\
\text { yellow } \\
\text { diet }\end{array}$} & \multirow{2}{*}{$\mathrm{QO}_{2}$} & \multicolumn{2}{|c|}{ Succinate } & \multicolumn{2}{|c|}{$\mathrm{p}-\mathrm{C}_{6} \mathrm{H}_{4}\left(\mathrm{NH}_{2}\right)$} \\
\hline & & $\mathrm{QO}_{2}$ & Per cent & $\mathrm{QO}_{2}$ & Per cent \\
\hline $\begin{array}{c}21 \\
32 \\
44 \\
49 \\
62 \\
76 \\
88 \\
95 \\
(113) \\
114 \\
127 \\
136 \\
150 \\
163 \\
186\end{array}$ & $\begin{array}{r}8.5 \\
8.1 \\
12.0 \\
8.0 \\
7.3 \\
14.8 \\
13.5 \\
10.2 \\
11.5 \\
11.0 \\
12.1 \\
11.7 \\
10.7 \\
10.3 \\
8.2\end{array}$ & $\begin{array}{l}18.5 \\
19.4 \\
31.7 \\
20.0 \\
27.7 \\
25.0 \\
23.1 \\
19.2 \\
41 \\
18.4 \\
15.8 \\
14.3 \\
12.5 \\
7.3 \\
9.0\end{array}$ & $\begin{array}{r}+118 \\
+140 \\
+164 \\
+150 \\
+279 \\
+69 \\
+71 \\
+89 \\
(+256) \\
+67 \\
+31 \\
+22 \\
+23 \\
-29 \\
+10\end{array}$ & $\begin{array}{l}21.0 \\
16.3 \\
24.3 \\
16.5 \\
27.7 \\
16.6 \\
24.6 \\
20.6 \\
37.3 \\
21.5 \\
20.9 \\
15.0 \\
14.7 \\
9.8 \\
9.8\end{array}$ & $\begin{array}{r}+147 \\
+101 \\
+103 \\
+106 \\
+279 \\
+12 \\
+82 \\
+102 \\
(+224) \\
+95 \\
+73 \\
+28 \\
+44 \\
-5 \\
+20\end{array}$ \\
\hline
\end{tabular}

the figure, during the first $\mathbf{5 0}$ days, succinoxidase activity remained high and, indeed, may even have increased somewhat. About the 70th day, however, a rather rapid decline in the activity of this physiologic unit set in, and eventually reached the level already found (1) in malignant tissue. At this point, however, pathologic examination failed to reveal frankly malignant tissue, although there were obvious departures from the normal, including definite cirrhosis of the liver and variation in nuclear size. Pertinent reports by Dr. Harry S. N. Greene were as follows:

70th day. Section of liver. The cells show pronounced cytoplasmic degeneration with nuclei which vary markedly in size, shape, and staining 
quality. There is a slight increase in peri-portal connective tissue.

137th day. Section of liver showing more pronounced cytoplasmic degeneration, more widespread variation in nuclear size, shape, and staining qualities, and greater fibrosis than in 70th day rat liver.

The first definite tumor appeared on the 163rd day. It was a characteristic hepatoma such as Kinosita (9) and Orr (10) described. As will be observed from Table I and Figure 1, the suc-

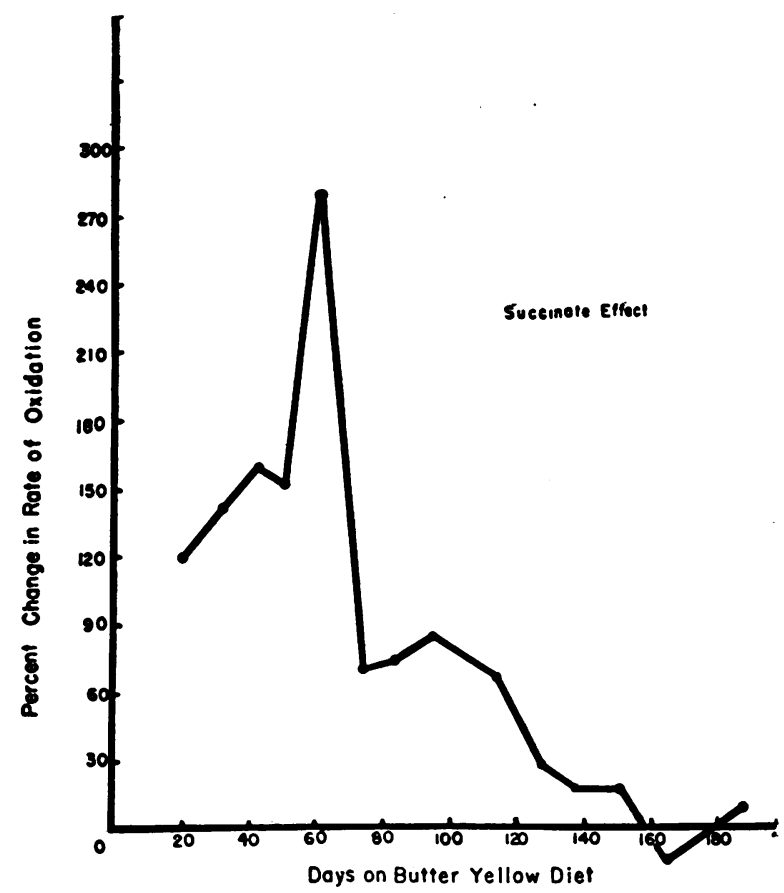

Fig. 1. Oxidative Behavior of Livers of Rats Fed Butter Yellow

On a diet containing "butter yellow," the livers of rats lose succinoxidase responsiveness. At 160 days, frank cancer appears.

cinoxidase and cytochrome activities had reached the base-line at this time.

In surveying these results, it is clear that the cytochrome system activity had become suspiciously low many days before a state of undeniable cancer had been reached. In other words, diminution in the responsiveness of this physiologic unit was a prelude to the appearance of cancer, but did not necessarily imply by its low value that cancer was already present. It would be interesting to know whether the resumption of a normal diet, high in vitamin, at the 50 th or the 140th day would result in the restoration of cytochrome system activity as the danger of neoplasm passed. This problem is being studied (11).

Simultaneous studies of aerobic glycolysis from the 20th day onward showed that at a time when the cytochrome activity was already suspiciously low, but when pathological examination still failed to reveal frank cancer, no appreciable aerobic glycolysis was present (11). As soon as obvious cancer developed, however, i.e., at the 163rd day and thereafter, unmistakable aerobic glycolysis was found, in accordance with the reports of Burk, Behrens, and Sugiura (12) in similar material. In brief, the succinoxidase observations suggested the imminence of malignancy, but the appearance of aerobic glycolysis was more precisely related, in time, to the presence of recognizable cancer.

\section{Shope virus rabbit papilloma}

Similar studies were conducted with skin papilloma, produced in domestic rabbits by the inoculalation of virus. The inoculation was performed on February 19, 1941, with a preparation of virus kindly supplied by Dr. R. E. Shope. Thereafter, at appropriate intervals, biopsies were taken for simultaneous determination of $(a)$ succinoxidase responsiveness and cytochrome system responsiveness, (b) aerobic glycolysis, and (c) pathological examination. As shown in Table II and Figure 2 , during the first 7 weeks, the oxidative activity remained high and possibly even rose slightly. About the tenth week, however, a precipitate decline occurred in both the succinate and the paraphenylenediamine effects. Nevertheless, patho-

TABLE II

Shope virus papilloma

\begin{tabular}{|c|c|c|c|c|c|}
\hline \multirow{2}{*}{$\begin{array}{l}\text { Time after } \\
\text { inoculation } \\
\text { weeks }\end{array}$} & \multirow{2}{*}{$\mathrm{QO}_{2}$} & \multicolumn{2}{|c|}{ Succinate } & \multicolumn{2}{|c|}{$\mathrm{D}-\mathrm{C}_{6} \mathrm{H}_{4}\left(\mathrm{NH}_{2}\right)_{2}$} \\
\hline & & $\mathrm{Q}_{2}$ & $\Delta$ Per cent & $\mathbf{Q O}_{2}$ & $\Delta$ Per cent \\
\hline $\begin{array}{c}6 \\
7 \\
10 \\
14 \\
\\
46 \\
55 \\
79^{*}\end{array}$ & $\begin{array}{l}1.07 \\
0.28 \\
3.0 \\
2.6 \\
3.8 \\
3.7 \\
5.1 \\
4.2\end{array}$ & $\begin{array}{l}2.38 \\
1.05 \\
3.9 \\
2.7 \\
3.5 \\
3.4 \\
5.8 \\
5.0\end{array}$ & $\begin{array}{r}+222 \\
+382 \\
+\quad 28 \\
+\quad 4 \\
=\quad 9 \\
=\quad 8 \\
+\quad 14 \\
+\quad 19\end{array}$ & $\begin{array}{l}3.38 \\
1.22 \\
3.1 \\
2.9 \\
3.3 \\
5.2 \\
5.4 \\
6.8\end{array}$ & $\begin{array}{r}+316 \\
+440 \\
+\quad 1 \\
+\quad 14 \\
+14 \\
+\quad 40 \\
+\quad 6 \\
+60\end{array}$ \\
\hline
\end{tabular}

* At this stage the $Q_{\mathrm{CO}_{2}}^{\mathrm{O}_{2}}$ was 11.0 and the $Q_{\mathrm{CO}_{3}}^{\mathrm{N}_{3}}$ was 20.8 for dried tissue removed after the manometric determination. 


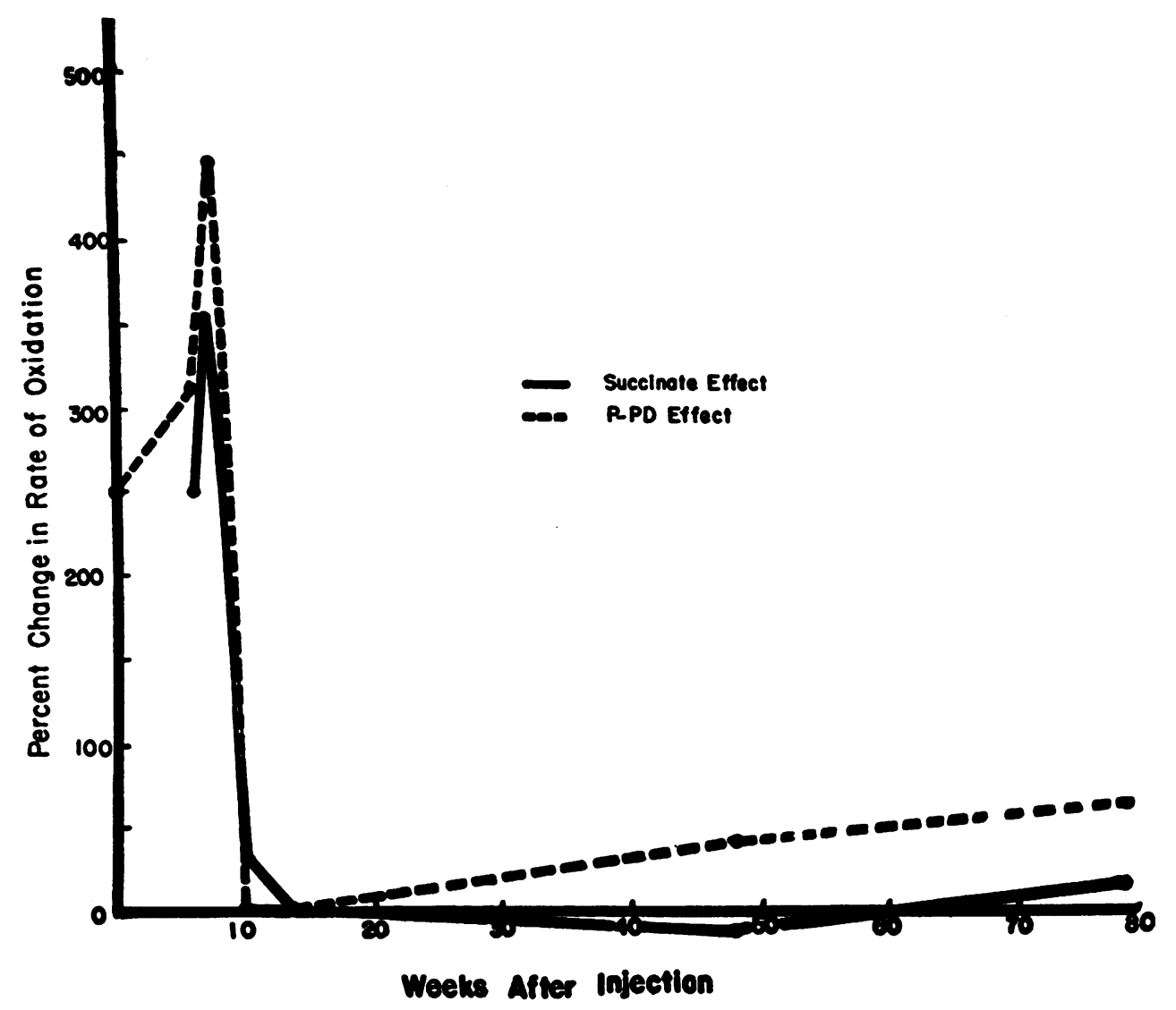

Fig. 2. Oxidative Behavior of Shope Virus Papilloma

Domestic rabbits, inoculated with Shope virus, develop a cutaneous papilloma which becomes malignant only after many months. Oxidative enzymes, however, decline in a few weeks.

logical examination showed only papilloma without frank cancer, and this status remained unchanged for approximately a year. Examination at the 13th month showed low oxidative effect but practically no aerobic glycolysis. By pathological examination, the neoplasm was still non-cancerous. In brief, these findings harmonize with those in the preceding section. Loss of oxidative activity indicates neoplasm but does not guarantee the presence of frank cancer.

After 79 weeks, the last of 3 animals was sacrificed on Oct. 3, 1942. Autopsy revealed carcinoma with metastasis to an inguinal lymph node.

Pathological report on a section of skin papilloma at 55 weeks was as follows: The epithelium rests on a well-defined basement membrane and there are no morphological changes suggesting autonomy.

Pathological report at autopsy, 79 weeks, was as follows: The tumor is composed of massive squamous cells in typical carcinomatous pattern. There is marked irregularity in nuclear size and shape with many giant nuclei. There are numerous mitotic figures and large areas of necrosis. The tumor cells are invading subcutaneous tissues. Invasion is accompanied by a very slight lymphocytic infiltration.

\section{Implanted mouse tumors}

Observations were made with the following implanted mouse tumors: Sarcoma 180, Yale tumor no. 1, and rhabdomyosarcoma produced with methyl cholanthrene, as described in the previous report (1). As shown in Table III, these results verify previous findings with this technique.

The results with Yale tumor no. 1, borne by Bar Harbor strain A mice and by Strong strain $A$, are of special interest. They were contrasted with data from normal lung tissue of the identical 
TABLE III

Yale tumor

\begin{tabular}{|c|c|c|c|c|c|}
\hline \multirow{2}{*}{\multicolumn{2}{|c|}{$\mathbf{Q O}_{2}$}} & \multicolumn{2}{|c|}{ Succinate } & \multicolumn{2}{|c|}{$\mathrm{p}-\mathrm{C}_{6} \mathrm{H}_{4}\left(\mathrm{NH}_{2}\right)_{2}$} \\
\hline & & $\mathrm{QO}_{2}$ & $\underset{\text { Per cent }}{\Delta}$ & $\mathrm{QO}_{2}$ & $\underset{\text { Per cent }}{\Delta}$ \\
\hline & $\begin{array}{l}9.6 \\
6.0 \\
8.7 \\
8.7 \\
7.4 \\
6.6 \\
2.4 \\
4.0 \\
7.9 \\
5.5 \\
6.8 \\
5.7\end{array}$ & $\begin{array}{r}9.6 \\
6.8 \\
9.4 \\
9.8 \\
10.1 \\
6.8 \\
2.2 \\
5.3 \\
8.3 \\
3.8 \\
6.8 \\
3.6\end{array}$ & $\begin{array}{c}0 \\
+20.3 \\
+8.0 \\
+12.6 \\
+36.0 \\
+3.0 \\
+8.3 \\
+33.0 \\
+5.1 \\
=11.0 \\
=0 \\
-37.0\end{array}$ & $\begin{array}{r}11.3 \\
12.6 \\
10.9 \\
9.8 \\
12.5 \\
9.4 \\
3.2 \\
4.4 \\
8.4 \\
8.0 \\
4.1 \\
3.9\end{array}$ & $\begin{array}{r}+11.2 \\
+110.0 \\
+25.3 \\
+12.6 \\
+68.7 \\
+38.9 \\
+33.0 \\
+10.0 \\
+6.3 \\
+46.0 \\
=40.0 \\
-32.0\end{array}$ \\
\hline Mean & 6.6 & 6.8 & +3.3 & 8.2 & +24.3 \\
\hline
\end{tabular}

Lung from Yale tumor host

\begin{tabular}{|c|c|c|c|c|c|}
\hline & $\begin{array}{r}11.7 \\
8.4 \\
9.0 \\
5.8 \\
4.6 \\
4.1 \\
6.0 \\
3.0 \\
4.9 \\
5.4 \\
5.2 \\
4.9\end{array}$ & $\begin{array}{r}18.7 \\
10.7 \\
16.3 \\
7.9 \\
4.8 \\
9.5 \\
7.2 \\
10.5 \\
7.6\end{array}$ & $\begin{array}{r}+123 \\
+19 \\
+182 \\
+92.6 \\
-20.0 \\
+93.8 \\
+34.2 \\
+100.9 \\
+55.1\end{array}$ & $\begin{array}{r}28.9 \\
17.5 \\
11.5 \\
12.3 \\
9.6 \\
\\
8.9 \\
8.7 \\
9.3 \\
8.4 \\
8.7 \\
9.1\end{array}$ & $\begin{array}{l}+147.0 \\
+108 \\
+28 \\
+112 \\
+108.7 \\
+\quad 48.3 \\
+191.6 \\
+89.8 \\
+\quad 56.5 \\
+66.6 \\
+85.7\end{array}$ \\
\hline Mean & 5.1 & 10.1 & +65.5 & 12.1 & +98.3 \\
\hline
\end{tabular}

Comparison of oxidative behavior of Yale tumor to other tumors in mice

\begin{tabular}{|c|c|c|c|c|c|}
\hline & \multirow{2}{*}{$\mathrm{QO}_{2}$} & \multicolumn{2}{|c|}{ Succinate } & \multicolumn{2}{|c|}{$\mathrm{p}-\mathrm{C}_{6} \mathrm{H}_{4}\left(\mathrm{NH}_{2}\right)_{2}$} \\
\hline & & $\mathrm{QO}_{2}$ & $\begin{array}{l}\text { Per cent } \\
\text { change }\end{array}$ & $\mathrm{QO}_{2}$ & $\begin{array}{c}\text { Per cent } \\
\text { change }\end{array}$ \\
\hline $\begin{array}{l}\text { Sarcoma } 180 \\
\text { Lymphosarcoma } \\
\text { Rhabdomyosarcoma } \\
\text { Rhabdomyosarcoma } \\
\text { Mouse "chest tumor" } \\
\text { (Gardner) } \\
\text { Yale tumor }\end{array}$ & $\begin{array}{r}8.9 \\
8.8 \\
11.4 \\
10.9 \\
7.6 \\
6.6\end{array}$ & $\begin{array}{r}10.6 \\
9.1 \\
11.8 \\
10.9 \\
7.0 \\
6.8\end{array}$ & $\begin{array}{l}+19 \\
+3.4 \\
+3.5 \\
0 \\
-7.9 \\
+3.3\end{array}$ & $\begin{array}{r}10.2 \\
7.7 \\
14.5 \\
13.5 \\
8.8 \\
8.2\end{array}$ & $\begin{array}{l}+15 \\
-13 \\
+27 \\
+24 \\
+16 \\
+24.3\end{array}$ \\
\hline
\end{tabular}

hosts. This tumor was found by Stern (5) to show a very strong cytochrome-a, $-b$, and -c spectrum, in harmony with Ball's statement (13) that Jensen rat sarcoma contains cytochrome-a, $-\mathrm{b}$, and -c in abundance. These observations, however, were merely qualitative in nature. Subsequent quantitative analyses of the Yale tumor by Potter (14) showed that the cytochrome concentration was lower than that of most normal tissues.
Similar quantitative findings in other tumors had been reported by v. Euler (2) and by Stotz (3). It so happens that the concentration of cytochrome-c in normal lung tissue is approximately that of this tumor (15). Comparative results, therefore, should throw light upon the following point. Do our measurements reflect merely the concentration of cytochrome-c per se, or do they reflect rather the over-all activity of the entire physiological unit known as the cytochrome system, including cytochrome oxidase? Our data appear in Table III.

It will be noted that the response of Yale tumor no. 1 did not appear significantly different from that found for other animal tumors, although its content of cytochrome-c is relatively high. On the contrary, in the case of lung, many of the values approach the range found for normal tissues. These results suggest, therefore, that our method does not measure simply the absolute concentration of cytochrome-c, but may reflect as well the activity of cytochrome oxidase or other limiting factors. As described in the previous communication (1), this problem is further complicated by the extent of stroma and necrosis. On the whole, we prefer to regard the method as a test of responsiveness of cytochrome-oxidase system activity, rather than as an absolute measurement of cytochrome-c concentration.

In Table III also are listed mean values on several miscellaneous tissues.

It should be emphasized that the manometric tests employed represent methods for the determination of cytochrome-c concentration only if special care is taken to make the latter the limiting factor. As carried out, the tests yield only an indication of the over-all activity of the entire oxidative systems involved. (Cytochrome oxidase $\rightarrow$ Cytochrome $-c \rightarrow$ Succinic dehydrogenase.) The case of Yale tumor no. 1 and lung tissue suggests that in the tumor tissue, the limiting factor is the cytochrome oxidase rather than the cytochrome-c concentration. This could be verified by the use of homogenized tissue with the addition of purified heart cytochrome-c.

\section{Human tissues}

This method has been applied to 6 specimens of normal human tissue and to 22 biopsies of human tumor from the operating rooms of the New Haven Hospital. For these specimens, we are indebted to the surgical staff of the New Haven Hospital and especially to Drs. Samuel C. 
Harvey and Clyde L. Deming. The data are summarized in Tables IV and V, which include also the pathological diagnosis of Dr. H. S. N. Greene. With a few exceptions or special cases, as described below, these data in human tumors corroborate the findings in animal neoplasia. A series of values for normal skin, for gumma of the skin, and for several cutaneous neoplasms is illustrated by Figure 3.

It will be observed that all of the normal human adult tissues thus far studied show a high oxidative response. Conversely, all of the frankly malignant human cancers show a poor oxidative response, with the partial exception of one adenocarcinoma of the kidney, i.e., Case No. 20, Table V. Even in this exceptional case, the succinate response was poor, and it is therefore conceivable that the paraphenylenediamine result represents a technical mischance, although there is no proof of this. The results obtained for normal human kidney and for 3 renal neoplasms are illustrated in Figure 4.

Certain neoplasms, however, require special comment. As shown in Table V, leukoplakia of. the tongue, recently treated with $\mathrm{x}$-ray, behaved like a normal tissue. The pathological report on

TABLE IV

Oxidative behavior of normal human tissues

\begin{tabular}{|c|c|c|c|c|c|c|c|c|}
\hline & \multirow{2}{*}{$\mathrm{QO}_{2}$} & \multicolumn{2}{|c|}{ Succinate } & \multicolumn{2}{|c|}{$\mathrm{p}-\mathrm{C}_{6} \mathrm{H}_{4}\left(\mathrm{NH}_{2}\right)_{2}$} & \multirow{2}{*}{$\begin{array}{c}\text { Case } \\
\text { number }\end{array}$} & \multirow{2}{*}{ Age } & \multirow{2}{*}{ Sex } \\
\hline & & $\mathrm{QO}_{2}$ & $\stackrel{\Delta}{\text { Per cent }}$ & $\mathrm{Q}_{2}$ & $\stackrel{\Delta}{\text { Per cent }}$ & & & \\
\hline $\begin{array}{l}\text { Kidney } \\
\text { Skin } \\
\text { Thyroid } \\
\text { Prostate } \\
\text { Testicle (from cancer of prostate) } \\
\text { Homologous normal tissue of cancer of rectum }\end{array}$ & $\begin{array}{l}9.2 \\
4.0 \\
5.6 \\
6.5 \\
6.4 \\
4.2\end{array}$ & $\begin{array}{r}20.9 \\
10.3 \\
13.1 \\
17.9 \\
13.2 \\
8.4\end{array}$ & $\begin{array}{l}+127 \\
+158 \\
+134 \\
+176 \\
+107 \\
+100\end{array}$ & $\begin{array}{r}20.0 \\
8.7 \\
12.2 \\
17.7 \\
17.0 \\
8.1\end{array}$ & $\begin{array}{l}+118 \\
+118 \\
+118 \\
+173 \\
+167 \\
+93\end{array}$ & $\begin{array}{l}\text { B-21466 } \\
88073 \\
\text { A-2095 } \\
\text { B-21787 } \\
\text { A-12514 } \\
\text { B-17040 }\end{array}$ & $\begin{array}{l}42 \\
17 \\
58 \\
62 \\
67 \\
74\end{array}$ & $\begin{array}{l}\mathbf{M} \\
\mathbf{M} \\
\mathbf{M} \\
\mathbf{M} \\
\mathbf{F}\end{array}$ \\
\hline Tongue (leukoplakia) & 3.1 & 7.8 & +152 & 9.7 & +213 & B-22307 & $\cdot 35$ & $\mathbf{F}$ \\
\hline
\end{tabular}

TABLE V

Oxidative behavior of human tumors, surgically excised

\begin{tabular}{|c|c|c|c|c|c|c|c|c|}
\hline & \multirow{2}{*}{$\mathrm{OO}_{2}$} & \multicolumn{2}{|c|}{ Succinate } & \multicolumn{2}{|c|}{$\mathrm{p}-\mathrm{C}_{6} \mathrm{H}_{4}\left(\mathrm{NH}_{2}\right)_{2}$} & \multirow{2}{*}{$\begin{array}{c}\text { Case } \\
\text { number }\end{array}$} & \multirow{2}{*}{ Age } & \multirow{2}{*}{ Sex } \\
\hline & & $\mathrm{QO}_{2}$ & $\underset{\text { Per cent }}{\Delta}$ & $\mathbf{Q O}_{2}$ & $\underset{\text { Per cent }}{\Delta}$ & & & \\
\hline $\begin{array}{l}\text { Rectal-sigmoid adenocarcinoma } \\
\text { Rectal-sigmoid adenocarcinoma } \\
\text { Rectal-sigmoid adenocarcinoma } \\
\text { Breast papilloma } \\
\text { Rectal-sigmoid adenocarcinoma } \\
\text { Chronic cystic mastitis* } \\
\text { Fibroxanthoma } \\
\text { Synovial sarcoma } \\
\text { Verrucous tumor of neck } \\
\text { Kidney tumor (sympathicoblastoma) } \\
\text { Cancer of stomach } \\
\text { Fibroxanthoma of leg } \\
\text { Brain tumor } \\
\text { Cancer of rectum lymph-node metastasis } \\
\text { Kidney tumor-hypernephroma } \\
\text { Adenocarcinoma-splenic flexure } \\
\text { Basal cell carcinoma } \\
\text { Lymphoblastoma-inguinal node } \\
\text { Cancer of stomach-lymph node } \\
\text { Adenocarcinoma-kidney } \\
\text { Sigmoid tumor } \\
\text { Testicular tumor }\end{array}$ & $\begin{array}{r}4.9 \\
9.0 \\
8.9 \\
8.7 \\
8.0 \\
4.8 \\
10.8 \\
7.4 \\
3.0 \\
13.3 \\
9.4 \\
10.1 \\
8.9 \\
5.3 \\
4.5 \\
10.8 \\
7.3 \\
7.7 \\
11.2 \\
9.7 \\
6.6 \\
7.8\end{array}$ & $\begin{array}{r}4.9 \\
10.8 \\
10.3 \\
12.3 \\
9.8 \\
3.8 \\
15.9 \\
8.2 \\
3.7 \\
11.9 \\
9.5 \\
13.5 \\
11.3 \\
7.2 \\
4.6 \\
16.3 \\
5.2 \\
6.5 \\
14.2 \\
9.9 \\
8.2 \\
13.7\end{array}$ & $\begin{array}{r}0 \\
+20 \\
+16 \\
+41 \\
+23 \\
+21 \\
+47 \\
+11 \\
+23 \\
+10 \\
+1 \\
+34 \\
+27 \\
+36 \\
+2 \\
+51 \\
-29 \\
-16 \\
+27 \\
+21 \\
+24 \\
+76\end{array}$ & $\begin{array}{r}4.9 \\
9.7 \\
10.5 \\
8.1 \\
9.3 \\
4.3 \\
15.0 \\
10 \\
3.6 \\
14.2 \\
12.2 \\
7.3 \\
7.1 \\
7.2 \\
5.3 \\
13.9 \\
6.9 \\
10.6 \\
19.1 \\
8.6 \\
6.6\end{array}$ & $\begin{array}{l}\quad 0 \\
+7.8 \\
+18 \\
+\quad 6.9 \\
+16 \\
+10 \\
+39 \\
+35 \\
+20 \\
+6.8 \\
+30 \\
+28 \\
-20 \\
+36 \\
+18 \\
+27 \\
+\quad 6 \\
+38 \\
+ \\
+9 \\
+30 \\
+15\end{array}$ & $\begin{array}{c}\text { A-64665 } \\
\text { B-20965 } \\
\text { B-19047 } \\
75661 \\
18343 \\
15664 \\
\text { B-21381 } \\
\text { A-6959 } \\
\text { O-P.D. } \\
\text { B-8942 } \\
\text { B-21828 } \\
\text { A-84021 } \\
\text { A-63414 } \\
\text { B-17040 } \\
\text { B-22176 } \\
26242 \\
\text { B-22637 } \\
\text { A-41155 } \\
\text { B-22907 } \\
\text { B-11925 } \\
\text { B-22962 } \\
\text { PP-212A }\end{array}$ & $\begin{array}{l}\mathbf{5 5} \\
61 \\
71 \\
32 \\
72 \\
36 \\
48 \\
67 \\
21 \\
1 \\
41 \\
68 \\
27 \\
74 \\
52 \\
\mathbf{5 5} \\
\mathbf{8 2} \\
\mathbf{5 6} \\
\mathbf{5 8} \\
\mathbf{7 4} \\
\mathbf{4 2} \\
\mathbf{7 4}\end{array}$ & $\begin{array}{l}F \\
F \\
M \\
F \\
F \\
F \\
M \\
M \\
M \\
F \\
M \\
M \\
F \\
F \\
M \\
F \\
M \\
M \\
F \\
M \\
F \\
M\end{array}$ \\
\hline
\end{tabular}

* Arbitrarily placed here. 


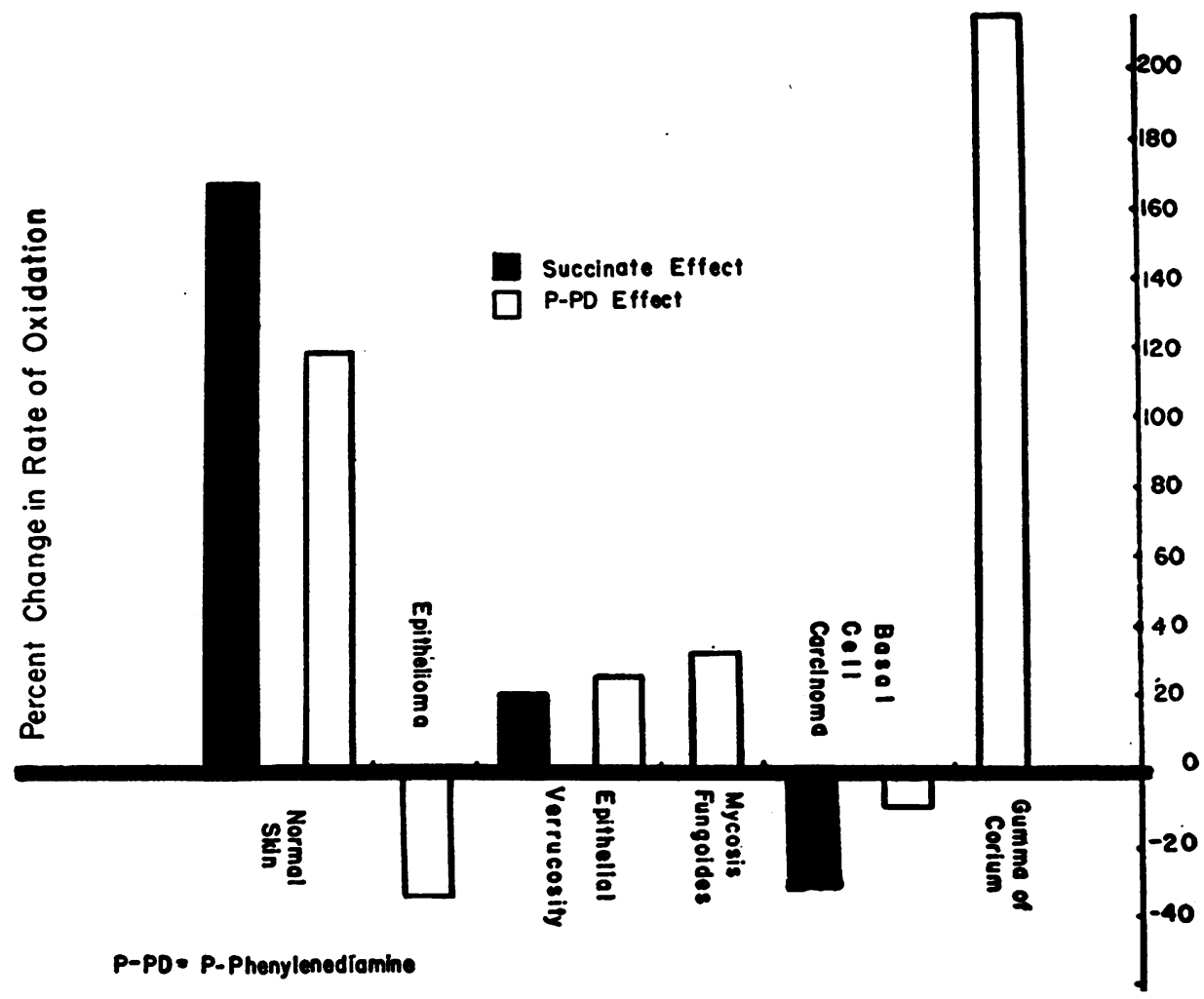

Fig. 3. Oxidative Behavior of Homologous Human Tissues

Normal human skin and cutaneous lesions, compared. Neoplasia shows loss of oxidative enzymes whereas granuloma behaves normally.

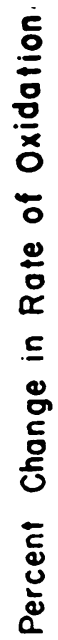

Succinole Effect

P. PO Effect
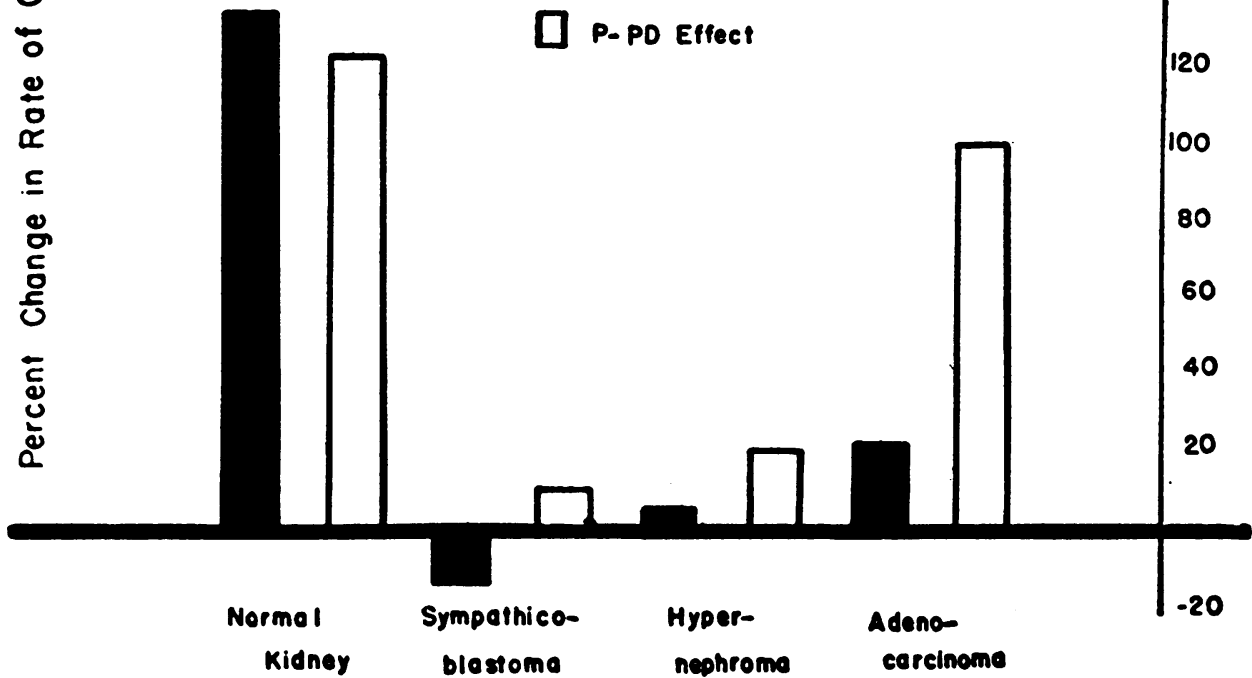

\section{P.PO. P-Fnenylencromine}

Fig. 4. Oxidative Behavior of Homologous Human Tissues (Kidney) Normal human kidney compared with human renal neoplasms. 
this biopsy from Dr. H. S. N. Greene was as follows: Leukoplakia with early malignant change.

Likewise, as shown in Table V, chronic cystic mastitis behaved as a neoplasm. The biopsy report from Dr. H. S. N. Greene from this tissue was as follows: Breast tumor with increase of fibrous connective tissue and sparse glands.

As shown in Figure 5, the loss of oxidative activity in a cancer-bearing organ (rectal mucosa)

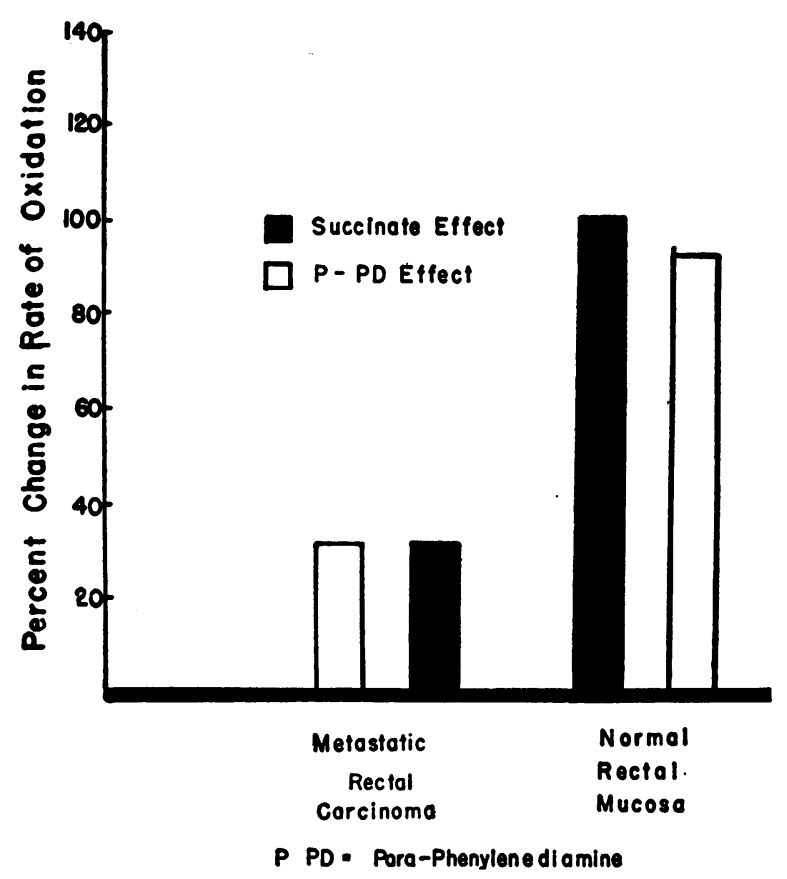

Fig. 5. Oxidative Behavior of Homologous Human Tissues (Rectum)

Normal rectal mucosa and carcinoma from the same patient.

did not extend to the nearby normal mucosa. In short, the loss of oxidative activity occurs only in the neoplastic tissue, or possibly in cells very intimately associated with it.

\section{Human embryos}

Similar observations with human embryos are being studied in collaboration with Dr. H. S. N. Greene, in connection with observations on transplantability. These data will be the subject of a later report.

\section{COMMENT}

These data bear on two general problems, first, the classification of any given tissue by biochemi- cal criteria and, secondly, the chemical pathology of the neoplastic cell.

As regards the possible classification of tissues in terms of biochemical findings, it seems likely that no strictly normal adult tissue will be found wanting in cytochrome system activity. It seems clear, also, that nearly all types of highly malignant cancers have deficient cytochrome system activities. This is true for various human malignancies, as well as for the common, well established transplantable and induced animal tumors. It is interesting that carcinogenesis, both by a chemical agent and by a virus, produces the same effect.

It must be noted, however, that the findings of diminished cytochrome activity, as, for example, in a cutaneous wart (Case No. 9, Table V), does not in itself imply malignancy. It probably does suggest that the first step toward autonomous growth has been accomplished; but it is possible that this benign stage may never be exceeded, despite the persistently deficient cytochrome system activity. In other words, further chemical changes must be established before the chemical classification of cancer, i.e., "frank malignancy," can be attributed to a given specimen. Among such changes, which are considered highly suspicious at the present date, are the appearance of high aerobic glycolysis and the peculiarity in ammonia metabolism described in a previous communication (16). Presumably, there are concomitant alterations in enzyme systems which might afford a more specific index of such changes.

Of special interest are the granulomata, certain types of leukoplakia, and the circulating leukocytes and bone marrow of human leukemia-all of which show high oxidative activity. This finding distinguishes such diseases from the usual types of neoplastic tissues. With respect to lymphoid tissue, it is suggestive that preliminary observations $(1,11)$ show that the nodes of well-developed Hodgkin's malignant lymphoma behave like normal tissues, whereas metastasizing lymphosarcoma behaves like a neoplasm when studied by the present technique.

As regards the mechanism of carcinogenesis, these data suggest that a first step in the de-differentiation of adult tissue is the loss of cytochrome system activity. The data may be interpreted in two ways, i.e., (1) that in an island of normal 
tissue a few cells suddenly lose most of their cytochrome; or (2) that throughout a section of tissue destined to become malignant or neoplastic all of the cells suffer a gradual diminution in oxidative ability. The collateral histological studies favor the latter alternative. In either case, it should be emphasized that the test herein described demonstrates a shift from normal to hyperplastic or neoplastic cells but not necessarily from neoplastic to cancer cells.

\section{SUMMARY}

A series of human and animal neoplasms has been investigated for their biochemical activity in relation to their pathological status. The chemical studies included cytochrome-oxidase system or succinoxidase activities and aerobic glycolysis. In general, most neoplasms are deficient in the first two of these, but only. frank cancers exhibit characteristic changes involving all three criteria. In animals developing neoplasia under the influence of a chemical carcinogenic agent or of a virus, loss of cytochrome system activity definitely precedes the histological appearance of frank malignancy and the appearance of aerobic glycolysis. Neoplastic tissue which is obviously. not malignant may show striking diminution in this capacity for oxidative activity. These findings are discussed (1) as chemical criteria of neoplasia and (2) as evidence that the process of carcinogenesis involves a preliminary loss of oxidase activity.

\section{BIBLIOGRAPHY}

1. Craig, F. N., Bassett, A. M., and Salter, W. T., Artificial benignancy of neoplasm. VI. Observations on the oxidative behavior of tumors, arti- ficially benign tumors, and homologous normal tissues. Cancer Research, 1941, 1, 869.

2. v. Euler, H., and Hellstrom, H., Enzymatische Sarkomstudien I. Einfluss der Cytochromkomponenten und der Diaphorase auf die Dehydrierung von 1und d-Lactat und Succinat. Ztschr. f. physiol. Chem., 1939, 260, 163.

3. Stotz, E., The estimation and distribution of cytochrome oxidase and cytochrome $\mathrm{C}$ in rat tissues. J. Biol. Chem., 1939, 131, 555.

4. Potter, V. R., Phosphorylation Theories and Tumor Metabolism. In A Symposium on Respiratory Enzymes. Univ. of Wisc. Press, Madison, 1942, p. 233.

5. Stern, K., Personal communication.

6. Meyer, O. O., McTiernan, C., and Salter, W. T., The utilization of simple derivatives of glucose by mouse sarcoma. Am. J. Cancer, 1934, 22, 76.

7. Warburg, O., Editor, The Metabolism of Tumours. Constable and Co. Ltd., London, 1930.

8. Kensler, C. J., Sugiura, K., and Rhoads, C. P., Coenzyme $I$ and riboflavin content of livers of rats red butter yellow. Science, 1940, 91, 623 .

9. Kinosita, R., Studies on cancerogenic chemical substances. Trans. Soc. path. Jap., 1937, 27, 665.

10. Orr, J. W., Histology of rat's liver during course of carcinogenesis by butter yellow (p-dimethylaminoazobenzene). J. Path. and Bact., 1940, 50, 393.

11. Unpublished data.

12. Burk, D., Behrens, O. K., and Sugiura, K., Metabolism of butter yellow rat liver cancers. Cancer Research, Society Proceedings, 1941, 1, 733.

13. Ball, E. G., Discussion on Stotz paper; Cytochrome oxidase and cytochrome. Cold Spring Harbor Symposia, 1939, 7, 111.

14. Potter, V. R., Personal communication.

15. Potter, V. R., and DuBois, K. P., The quantitative determination of cytochrome C. J. Biol. Chem., 1942, 142, 417.

16. Salter, W. T., and Robb, P. D., Ammonia production by sarcoma. The sparing effect of carbohydrate. Am. J. Cancer, 1934, 22, 87. 